\title{
IDENTIFIYING THE SUCCESSFULNESS OF A PROBLEM-BASED LEARNING IN AN UNDERGRADUATE MEDICAL EDUCATION PROGRAMME
}

Luh Ayu Viarini Dewi* Nancy M. Rehatta** Budi Utomo***

* Fakultas Kedokteran, Universitas Airlangga, Surabaya - INDONESIA

** Unit MERSDU, Fakultas Kedokteran, Universitas Airlangga, Surabaya - INDONESIA

*** Departemen IImu Kesehatan Masyarakat, Fakultas Kedokteran, Universitas Airlangga, Surabaya INDONESIA

\section{ABSTRACT}

Background: Problem Based Learning (PBL) is active learning with a student-centered approach where unstructured issues are used as starting points for inquiry and learning process and problem-based learning is one of the teaching uses stimulus materials in helping the college students figure out the problems, questions, or issues. In a PBL system, the instructor helps the students develop problem solving skills, self-directed learning, so students can identify what they need to know how to know and how to access new information they need.

Method: A cross-sectional study, using questionnaire distributed to 2015th generation of medical students in medical faculty of Airlangga University.

Results: Result of data settlement, got 2 ways that is subjective and objective way, by using questioner by student, and objective using result of graduation of the course. From the results of the study, the results of the study program are prepared from students who are directly graduated from the problem-based learning program.

Conclusion: This problem-based learning program is more successful than not using problem-based learning.

Keywords: Problem Based Learning, self-directed learning, pendekatan student-centered

\section{IDENTIFIKASI TINGKAT KEBERHASILAN PROGRAM PEMBELAJARAN PROBLEM-BASED LEARNING BAGI MAHASISWA FAKULTAS KEDOKTERAN}

\section{ABSTRAK}

Latar belakang: Problem Based Learning (PBL) adalah pembelajaran aktif dengan pendekatan berpusat pada siswa dimana isu-isu yang tidak terstruktur digunakan sebagai titik awal untuk proses tanya jawab. Pembelajaran berbasis masalah adalah salah satu pengajaran menggunakan bahan stimulus dalam membantu mahasiswa mengetahui masalah, pertanyaan, atau masalah. Dalam sistem PBL, Tutor membantu siswa mengembangkan keterampilan memecahkan masalah, belajar mandiri, sehingga siswa dapat mengidentifikasi yang perlu diketahui, mengetahui dan mengakses informasi baru yang mereka butuhkan.

Metode: Metode penelitian ini adalah penelitian cross-sectional. Dengan menggunakan kusioner untuk semester 4 yang menggunakan sistem pembelajaran pembelajaran berbasis masalah/problem-based learning.

Hasil: Hasil penelitian didapatkan 2 cara yaitu subjektif dan objektif, Metode yang diukur ialah secara subjektif yaitu persepsi mahasiswa yang diukur dari kuesioner, dan objektif dari hasil kelulusan mata kuliah, didapatkan data dengan cara subjektif $90 \%$ hasil kuesioner dari mahasiswa yang menyetujui manfaat dan

contact: luhayuviarinidewi@yahoo.com 
kelebihan adanya program problem based learning, dan data dengan cara objektif didapatkan 61\% mahasiswa yang lulus dengan sekali ujian tanpa mengulang,dari hasil subjektif dan objektif ini lebih besar pada mahasiswa kelompok program pembelajaran berbasis masalah/ problem based learning, dibandingkan program yang tidak menggunakan pembelajaran berbasis masalah/ problem based learning.

Kesimpulan: Program pembelajaran berbasis masalah ini lebih berhasil daripada tidak menggunakan pembelajaran berbasis masalah. Indikator yang kami gunakan ialah dengan melihat banyaknya mahasiswa yang lulus dalam sekali ujian tanpa mengulang dengan didukung data tambahan kuisioner yang merupakan persepsi mahasiswa yang mencakup pendapat seluruh mahasiswa tentang kelebihan problem-based learning.

Kata kunci: pembelajaran berbasis masalah., Belajar mandiri, pendekatan berbasis mahasiswa

\section{PENDAHULUAN}

Kedokteran terkenal dengan jurusan yang memiliki banyak peminat dengan materi yang susah untuk dipelajari sehingga menjadikan pandangan/pemikiran mahasiswa bahwa kedokteran memiliki materi yang banyak dan susah untuk dimengerti karena banyaknya materi yang bersifat menghafal. Mahasiswa yang memiliki kemampuan dengan daya ingat yang rendah menjadi merasa mata kuliah kedokteran ini menjadi mata kuliah yang kurang menarik, selain itu diperlukan keterampilan dalam pola berfikir, bertanggung jawab serta mengerti dan paham dengan mata kuliah di kedokteran. Mahasiswa akan berusaha mencari cara pembelajaran yang efektif untuk mempelajari mata kuliah di kedokteran.

Terkait dengan permasalahan seperti mata kuliah kedokteran susah untuk dipahami dan terkesan banyak menghafal tentunya dibutuhkan adanya Peningkatan mutu pembelajaran harus ditingkatkan untuk membantu mahasiswa dalam menjalani proses pembelajaran, peningkatan mutu pembelajaran dapat dicapai dengan dilaksanakannya pembelajaran yang inovatif dengan menempatkan mahasiswa sebagai pusat pembelajaran sehingga mahasiswa dapat belajar mandiri dan bermakna. Peningkatan mutu pembelajaran di era globalisasi ini juga sangat terkait dengan memanfaatkan kemajuan teknologi. Era globalisasi ini dibuktikan dengan Semakin berkembangnya teknologi informasi menyebabkan berbagai perubahan terjadi diberbagai lini kehidupan. Perkembangan teknologi informasi juga merambah dalam dunia pendidikan, untuk mencapai keseimbangan tersebut perlu adanya suatu program belajar yang dapat mengimbangi kemajuan era globalisasi dibidang pendidikan. dalam hal ini program pembelajaran yang diadakan ialah dengan menggunakan sistem belajar problem based learning, sistemnya selain pengajar yang memberikan materi seperti biasa, mahasiswa juga di tuntut untuk belajar mandiri dan kritis, untuk itu telah dijalankan model pembelajaran dengan pendekatan problem based learning di fakultas kedokteran. ${ }^{1}$ Model pembelajaran ini diperlukan mahasiswa dengan diberikan suatu permasalahan, Kemudian secara berkelompok sekitar 10 orang, setiap kelompok akan berusaha untuk mencari solusi dan penyelesaian atas permasalahan tersebut. Mereka diharapkan secara aktif dan mandiri mencari informasi yang valid dari berbagai sumber. Informasi dapat diperoleh dari bahan bacaan literatur, narasumber, dan lain sebagainya, dengan demikian Perkembangan teknologi informasi yang merambah dalam dunia pendidikan bertujuan mencapai keseimbangan yang dapat mengimbangi kemajuan era globalisasi dibidang pendidikan.

\section{METODE}

Penelitian ini merupakan jenis penelitian analitik observasional dengan desain observasional deskriptif dengan pendekatan cross sectional pada learning terhadap mahasiswa semester 4 dan semester 6 Fakultas Kedokteran Airlangga 2014, adapun kriteria tingkat keberhasilan program pembelajaran problem-based learning ini dengan melihat banyaknya siswa yang langsung lulus dalam mata pelajaran tersebut dan tidak mengulang melalui jalur semester pendek. Populasi penelitian adalah mahasiswa 
program studi S1 Pendidikan Dokter mahasiswa semester 4 angkatan 2015 dan mahasiswa semester 6 fakultas kedokteran Universitas Airlangga angkatan 2014. Sampel penelitian diambil dengan cara total sampling.

Kriteria inklusi dalam penelitian ini adalah mahasiswa dan mahasiswi semester 4 dan semester 6 fakultas kedokteran Universitas Airlangga angkatan 2014 yang bersedia. Kriteria eksklusi dalam penelitian ini adalah mahasiswa dan mahasiswi semester 4 dan semester 6 fakultas kedokteran Universitas Airlangga angkatan 2014 yang tidak bersedia.

Variabel bebas penelitian ini adalah Variabel yang akan dikaji dan dinilai ialah pendapat mahasiswa sesuai kuisioner yang diisi dan hasil ujian mata kuliah tersebut pada penelitian ini digunakan total populasi mahasiswa semester 4 dan semester 6 Fakultas Kedokteran Airlangga 2014. Teknik pengambilan data dalam penelitian ini adalah dengan menggunakan 2 cara subjektif dan objektif, subjektifnya menggunakan pengisian kuisioner oleh mahasiswa tersebut, dan objektifnya menggunakan hasil kelulusan mata kuliah tersebut.

Data hasil penelitian kuisioner yang diisi oleh responden sebagai data pendukung dan nilai hasil ujian mata kuliah yang diperoleh tersebut dalam tahap ini data diolah dan dianalisis secara deskriptif dengan menggunakan diagram batang. Tabel 1 menunjukkan definisi operasional dari nilai huruf dan angka.

Tabel 1. Definisi operasional

\begin{tabular}{ccc} 
Huruf & Nilai Angka & Keterangan \\
A & $>75,0$ & Langsung lulus \\
AB & $70,0-74,9$ & Langsung lulus \\
B & $65,5-69,9$ & Langsung lulus \\
BC & $60,0-64,9$ & Boleh mengulang \\
C & $55,0-59,0$ & Boleh mengulang \\
D & $40,0-54,9$ & Wajib mengulang \\
E & $<40,0$ & Wajib mengulang \\
\hline
\end{tabular}

\section{HASIL DAN PEMBAHASAN}

Penelitian yang dilakukan pada tahun 2014 dengan jumlah sampel 197 orang, beserta angkatan 2015 dengan total 188 untuk mengetahui tingkat keberhasilan metode pembelajaran problem-based learning pada mahasiswa semester 4 dan semester 6 Fakultas Kedokteran Airlangga angkatan 2014. Hasil penelitian dapat digambarkan pada gambar 1.

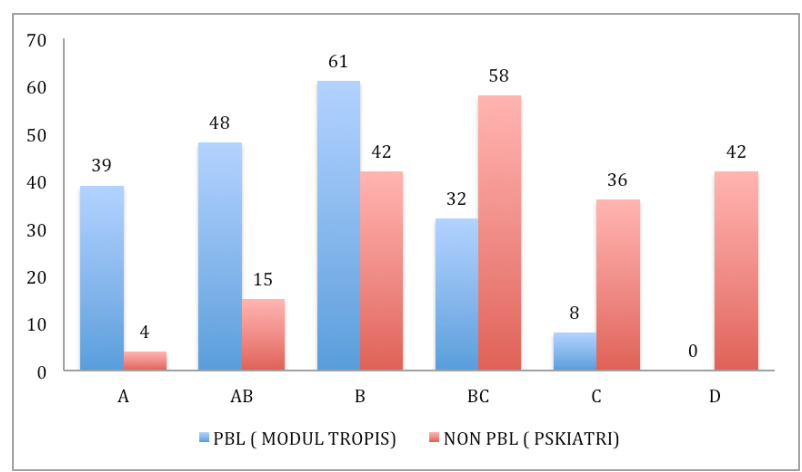

Gambar 1. Distribusi dan frekuensi nilai 'modul tropis' dan psikiatri

Distribusi dan frekuensi nilai "modul tropis" pada kelompok problem-based learning ialah 188 Mahasiswa yang mengikuti ujian Modul tropis. Diagram batang berwarna biru menunjukkan distribusi dan frekuensi nilai problem based learning dengan jumlah 39 Mahasiswa mendapatkan nilai A, 48 Mahasiswa mendapatkan nilai $A B, 61$ Mahasiswa mendapatkan nilai B, 32 Mahasiswa mendapatkan nilai BC, 8 Mahasiswa mendapatkan nilai $\mathrm{C}$, dan tidak ada mahasiswa yang mendapatkan nilai D. Banyaknya Distribusi dan frekuensi nilai modul tropis dalam nilai $\mathrm{A}, \mathrm{AB}, \mathrm{B}$ yang berarti mahasiswa tersebut langsung lulus dalam ujian lebih tinggi dibanding non problem based learning hal ini membuktikan keberhasilan adanya program pembelajaran problem based learning. Problem-based learning (PBL) ialah pembelajaran aktif dan pendekatan yang berpusat pada pelajar di mana masalah tidak terstruktur digunakan sebagai titik awal dan jangkar untuk penyelidikan dan pembelajaran proses. ${ }^{2}$

Distribusi dan frekuensi nilai "Psikiatri" pada kelompok non problem-based learning ialah 197 Mahasiswa yang mengikuti ujian Psikiatri. Diagram batang berwarna Merah menunjukkan distribusi 
dan frekuensi nilai non problem-based learning dalam mata kuliah psikiatri. dengan jumlah 4 Mahasiswa mendapatkan nilai A, 15 Mahasiswa mendapatkan nilai $\mathrm{AB}, 42$ Mahasiswa mendapatkan nilai B, 58 Mahasiswa mendapatkan nilai BC, 36 Mahasiswa mendapatkan nilai C, dan 42 mahasiswa yang mendapatkan nilai $D$. Kecilnya Distribusi dan frekuensi nilai psikiatri dalam nilai $\mathrm{A}, \mathrm{AB}, \mathrm{B}$ yang berarti mahasiswa tersebut langsung lulus dalam ujian lebih sedikit dibanding problem based learninghal ini membuktikan kurangnya keberhasilan tanpa adanya program pembelajaran problem based learning.

Distribusi dan frekuensi nilai modul tropis tinggi, hal ini tergambarkan banyaknya mahasiswa yang mendapatkan nilai $\mathrm{A}, \mathrm{AB}$, dan $\mathrm{B}$, dengan didukung pendapat-pendapat persepsi mahasiswa dalam kuisioner yang menilai kelebihan program problem based learning yang membentuk mahasiswa menjadi lebih mandiri. hal ini membuktikan banyaknya mahasiswa yang menjadi lebih mandiri, kreatif dan terampil dalam mengembangkan keterampilan berfikir, hal ini sesuai dengan hal yang dikemukakan Trianto2 bahwa problem-based learning bertujuan membantu siswa mengembangkan keterampilan berpikir dan keterampilan mengatasi masalah, belajar peranan orang dewasa yang autentik dan menjadi pembelajar yang mandiri. Problem based learning juga bukan hanya tentang proses pemecahan masalah, berdasarkan konstruktivisme di mana masalah realistis digunakan bersamaan dengan desain pembelajaran lingkungan dimana kegiatan inquiry, self-directed learning, information mining, dialog, dan pemecahan masalah kolaboratif tergabung. ${ }^{3} \mathrm{Hal}$ tersebut sama seperti mahasiswa kedokteran yang menggabungkan atau mengkolaborasikan self-directed learning dengan materi-materi yang ada dalam dunia kedokteran dengan berfikir kritis sesuai manfaat dari problem-based learning. Berpikir kritis terdapat keterampilan mengaplikasikan, menganalisa, mensintesa, mengevaluasi informasi yang diperoleh dan mengeneralisasi hasil yang diperolehdari observasi, pengalaman, refleksi, penalaran, atau komunikasi. ${ }^{4}$ Selain itu dengan menggunakan sistem problembased learning ketika siswa membutuhkan informasi, siswa lebih cenderung untuk bertanggung jawab untuk berusaha sendiri untuk memecahkan masalah karena siswa merasa bertanggung jawab bukan hanya untuk dirinya sendiri tetapi juga untuk kelompoknya. ${ }^{5}$ Dengan begitu mahasiswa akan lebih berkembang dan mandiri dan bertanggung jawab baik dalam diri sendiri maupun lingkungan sekitarnya.

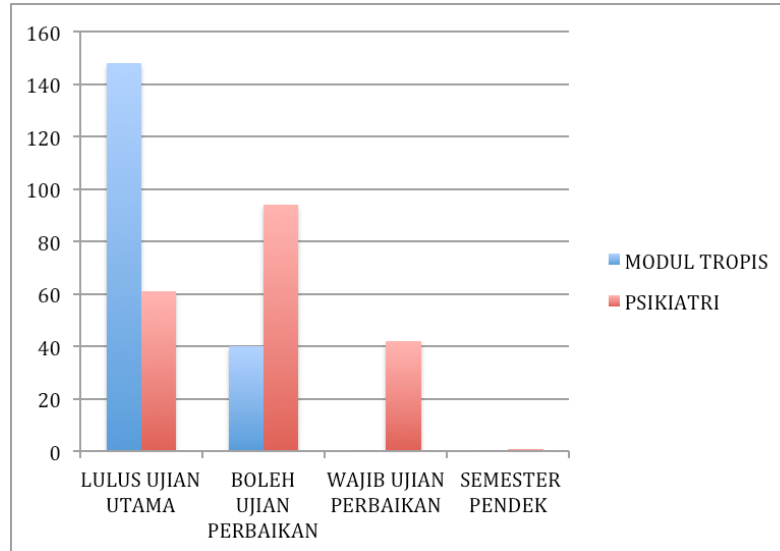

Gambar 2. Tingkat kelulusan program PBL pada modul tropis dan psikiatri

Gambar 2 menunjukkan keberhasilan program problem-based learning banyaknya mahasiswa yang langsung lulus ujian tanpa mengulang, hal ini tidak didapatkan dalam kelompok non problem-based learning yang hanya sedikit menghasilkan mahasiswa yang lulus dalam sekali ujian, ini menjelaskan bahwa pentingnya program problem-based learning juga meningkatkan kognitif dari setiap mahasiswa dan menghasilkan mahasiswa yang mandiri, dam memiliki kterampilan berfikir ini sejalan dengan Raimi dan Adeoye ${ }^{6}$ penggunaan problem-based learning sangat diperlukan untuk meningkatkan tingkat pencapaian nilai kognitif siswa. Serta pemahaman konsep siswa meningkat secara signifikan setelah melaui proses problem-based learning. ${ }^{5}$

Program pembelajaran tanpa adanya problem-based learning memiliki banyak kelemahan, sehingga banyak mahasiswa yang kurang mandiri dan kurang bertanggung jawab dalam menjalankan perannya menjadi mahasiswa. Dibandingkan dengan adanya program problem-based learning mengajarkan mahasiswa melalui sebuah kasus atau permasalahan, hal ini melatih para mahasiswa mandiri, seperti halnya dengan motivasi akan terus meningkat ketika mereka merasa bertanggung jawab untuk menemukan solusi dari permasalahan yang diperoleh. ${ }^{4}$ 
Kurangnya keberhasilan bagi pembelajaran non problem-based learning juga digambarkan karena kurangnya minat belajar mandiri, kurangnya rasa tanggung jawab terhadap diri sendiri, dalam perbandingan hasil kuisioner yang merupakan isi persepsi atau tanggapan dari mahasiswa banyak yang menilai lebih tertantang belajar mandiri pada modul yang menggunakan problem-based learning dari pada yang non problem-based learning, Kurangnya minat belajar mandiri juga membuat mahasiswa kekurangan motivasi untuk terus maju dan mandiri, beda halnya dengan menggunakan program problembased learning, dengan model pembelajaran melalui kasus dan praktik langsung secara mandiri untuk menekuni kasus tersebut sampai tuntas. belajar merupakan perubahan yang relatif permanen dalam kapasitas pribadi seseorang sebagai akibat pengolahan atas pengalaman yang diperolehnya dan praktik yang dilakukannya. ${ }^{7,8}$

\section{KESIMPULAN}

Penelitian ini didapatkan 2 cara yaitu subjektif dan objektif, subjektif dengan menggunakan persepsi mahasiswa yang diukur dengan kuesioner oleh mahasiswa yang bersangkutan, dan objektif dengan menggunakan hasil kelulusan mata kuliah, yang keduanya sama-sama menunjukan hasil yang optimal. Program Pembelajaran Problem based learning dinyatakan memberikan hasil yang baik dibandingkan non problem based learning.

\section{DEKLARASI KEPENTINGAN}

Artikel ini adalah bagian dari hasil disertasi pengarang pertama. Pengarang bertanggung jawab atas isi dan penulisan artikel ini. Adapun kontributor artikel ini adalah:
- Luh Ayu Viarini Dewi adalah pengarang pertama yang melakukan penelitian sekaligus menulis naskah publikasi ini.

- Prof. Dr. Nancy M. Rehatta, dr., SpAnKIC adalah pembimbing 1 dalam perencanaan, pelaksanaan penelitian, hingga pelaporan hasil penelitian serta penulisan naskah publikasi ini.

- Dr. H. Budi Utomo, dr., M.Kes adalah pembimbing 2 dalam perencanaan, pelaksanaan penelitian, hingga pelaporan hasil penelitian dan penulisan naskah publikasi ini.

\section{DAFTAR PUSTAKA}

1. Zaduqisti E. Pembelajaran berbasis masalah dalam prediksi dimensi milaibudaya. Pekalongan: CV Duta Media Utama; 2015.

2. Tan, OS. Problem based learning innovation: Using problem to power learning in 21st century. Thompson Learning; 2003.

3. Trianto. Model pembelajaran terpadu. Jakarta: PT Bumi Aksara; 2010.

4. Pastirik PJ. Using problem-based learning in a large classroom. Nurse Education in Practice. 2006;6:2617.

5. Paul R, Elder L. Miniature guide to critical thinking concepts and tools. Dillon Beach: Foundation for Critical Thinking Press; 2008.

6. Raimi SM, Adeoye FA. Problem based learning strategy and quantitative ability in college of education student's learning of integrated science. Ilo J of Edu. 2012;1-11.

7. Savery J. Overview of problem-based learning: definition and distinction. The Indisciplinary Journal of problem-based learning. 2006;1(1):9-20.

8. Yadav. Problem-based learning: influence on students' learning in an electical engineering course. J of Eng Educ. 2011;100(2):253-80. 